Notre Dame Law Review

Volume 92 | Issue 5

Article 12

$7-2017$

\title{
Reviewability and the "Law of Rules": An Essay in Honor of Justice Scalia
}

Adrian Vermeule

Harvard Law School

Follow this and additional works at: http://scholarship.law.nd.edu/ndlr

Part of the Judges Commons

Recommended Citation

92 Notre Dame L. Rev. 2163 (2017)

This Article is brought to you for free and open access by the Notre Dame Law Review at NDLScholarship. It has been accepted for inclusion in Notre

Dame Law Review by an authorized editor of NDLScholarship. For more information, please contact lawdr@nd.edu. 


\title{
REVIEWABILITY AND THE "LAW OF RULES": AN ESSAY IN HONOR OF JUSTICE SCALIA
}

\author{
Adrian Vermeule*

\section{INTRODUCTION}

In Washington v. Trump, ${ }^{1}$ the Ninth Circuit decision on the Administration's executive order on immigration, ${ }^{2}$ a critical moment occurred when the panel had to explain why the order was reviewable at all. Precedents like Kleindienst v. Mandel $^{3}$ had said that "when the Executive exercises [immigration authority] on the basis of a facially legitimate and bona fide reason, the courts will [not] look behind the exercise of that discretion." 4 The panel's response was to invoke an important distinction between the reviewability of general rules, on the one hand, and the reviewability of specific applications, on the other:

[T] he Mandel standard applies to lawsuits challenging an executive branch official's decision to issue or deny an individual visa based on the application of a congressionally enumerated standard to the particular facts presented by that visa application. The present case, by contrast, is not about the application of a specifically enumerated congressional policy to the particular facts presented in an individual visa application. Rather, the States are challenging the President's promulgation of sweeping immigration policy. Such exercises of policymaking authority at the highest levels of the political branches are plainly not subject to the Mandel standard. ${ }^{5}$

As we will see, this conception of reviewability ${ }^{6}$ - keyed to a distinction between general policies or rules and specific applications, with the former

(C) 2017 Adrian Vermeule. Individuals and nonprofit institutions may reproduce and distribute copies of this Essay in any format at or below cost, for educational purposes, so long as each copy identifies the author, provides a citation to the Notre Dame Law Review, and includes this provision in the copyright notice.

* Ralph S. Tyler Professor of Constitutional Law, Harvard Law School. Thanks to John Manning and Jeff Pojanowski for helpful comments.

1 Washington v. Trump, 847 F.3d 1151 (9th Cir. Feb. 9, 2017) (per curiam).

2 Exec. Order No. 13,769, 82 Fed. Reg. 8,977 (Jan. 27, 2017).

3 Kleindienst v. Mandel, 408 U.S. 753 (1972).

4 Id. at 770.

5 Trump, 847 F.3d at 1162.

6 In administrative law, "reviewability" has both a narrow technical meaning and a broader colloquial meaning. The narrow meaning involves the law surrounding the Administrative Procedure Act's (putative) presumption of reviewability and the exceptions to that presumption stated in section 701(a)(1) and (2). See 5 U.S.C. § 701(a) (2012). 
subject to review even if the latter would not be-is one that Justice Scalia wrestled with throughout his reviewability jurisprudence. Yet it is more or less directly the opposite of Justice Scalia's own conception. Justice Scalia developed a consistent approach to questions of reviewability: roughly, the idea that "general programs" and "general policies" are to be excluded from judicial review, and even general and legally binding agency rules may or may not be reviewable before enforcement. On this approach, the proper business of courts is to review specific applications of agency rules to particular parties. Notice that there are actually three possible subjects of review in play here: nonbinding policies and rules (such as "interpretive" rules); binding general rules ("legislative rules"); and applications. More on this shortly. For now, the focus is on the distinction between review of general and specific agency action, whether that action is embodied in a legally binding rule or in a nonbinding policy.

The approach featured in Washington v. Trump, by contrast, was propounded in several opinions by Justice John Paul Stevens. On that view, agencies should be more afforded more, not less, discretion to apply policies or rules in particular cases, whereas the proper business of the judiciary is to review the general legality of overall programs, policies, and rules. The Scalia view and the Stevens view obviously differ on the proper role of courts in an overall system of administrative law. For Justice Stevens, the role of courts is to say what the general rules of law are, leaving agencies (reasonable) discretion in application. For Justice Scalia, the role of courts is to decide cases, reviewing the legality of rules only insofar as necessary to that function-as a byproduct of deciding cases.

Furthermore, the two approaches differ as to the relationship between reviewability and the idea-perhaps Justice Scalia's most famous contribution to legal theory-that the rule of law is best understood as "a law of rules." On the Stevens view, reviewability should attempt to ensure that courts review the overall legality of programs and policies to keep the administrative state within the broad bounds of the rule of law. ${ }^{8}$ On that view, the "rule of law" is a "law of rules" in the sense that judicial power to say what the law is entails a power to examine the legality of general rules.

On the Scalia view, by contrast, the rule of law is a law of rules in a quite different sense. The judicial role is to review particular "cases and controversies," and the law of rules is a constraint on the sorts of reasons, grounds, or

The broader sense includes the narrow sense but adds any number of legal questions bearing on whether cases will be justiciable in court-questions of finality, ripeness, the "zone of interests" analysis (sometimes called "statutory standing"), constitutional standing, and even vague principles of interbranch comity and abstention. I will use "reviewability" in the second, capacious sense. As we will see, Justice Scalia evolved a consistent approach that expressed itself similarly under several different doctrinal rubrics.

7 See Antonin Scalia, The Rule of Law as a Law of Rules, 56 U. CHI. L. Rev. 1175 (1989).

8 See Chevron, 467 U.S. at 844; cf. Richard H. Fallon, Jr., Some Confusions About Due Process, Judicial Review, and Constitutional Remedies, 93 Colum. L. Rev. 309, 311 (1993) (articulating the goal of "keep[ing] government, overall and on average, tolerably within the bounds of law"). 
rationales courts may use to decide such cases. The rule of law requires courts to articulate grounds of sufficient generality that their disposition of particular cases is not arbitrary or unreasoned. The grounds of judicial decisionmaking must not display an excessively ad hoc, case-specific character. This conception underpins Justice Scalia's hostility to balancing tests across many areas of law.

Crucially, nothing in this conception is inconsistent with a conception of reviewability that is narrower than the Justice Stevens conception. The Justice Scalia conception admits into court only agency action at the point of specific application, but then demands that judges analyze the validity of that specific application under general rules. For Justice Stevens, the rule of law requires expansive judicial review of rules; for Justice Scalia, the rule of law, qua law of rules, operates primarily as a constraint on the types of rationales courts may give for their decisions of particular cases, once those cases are already in court. Both conceptions are internally consistent, but they are also opposites.

What difference does all this make? To see the main doctrinal difference between these two conceptions of reviewability, we have to clarify a tripartite distinction: between or among (1) review of nonbinding policies and rules, (2) review of legally binding general rules, and (3) review of specific applications. As Washington v. Trump explicitly indicates, and as Justice Stevens indicates as well in several decisions, one conception allows review of nonbinding rules and policies that are otherwise sufficiently final and definite to be reviewable. ${ }^{9}$ These nonbinding rules and policies may or may not have been formulated with valid statutory authority, adequate reasoning, and so forth.

On Justice Scalia's conception, by contrast, review of policies is never acceptable; broad policies and programs, as we will see, do not amount to reviewable agency "action." Agency applications of binding rules to specific

9 For nonbinding rules and policies, of course, the challenging hurdle is finality. In Bennett v. Spear, 520 U.S. 154 (1997), Justice Scalia wrote for the Court to articulate a twopart finality test that would allow review of agency action only if that action both consummated the agency's decisionmaking process, and produced "legal consequences." Id. at 178. This might be thought to bar review of any nonbinding agency action whatsoever. Later cases, however, have relaxed the apparent stringency of the requirement. See, e.g., U.S. Army Corps of Eng'rs v. Hawkes Co., Inc., 136 S. Ct. 1807, 1815, 1816 (2016) (applying the finality test to allow review of an agency "jurisdictional determination" and emphasizing the "pragmatic" character of the test). The emphasis on practical consequences creates space for review of nonbinding agency actions under at least some conditions, where the agency has definitively settled on a position. See, e.g., Safari Club Int'l v. Jewell, 842 F.3d 1280, 1289 (D.C. Cir. 2016) (explaining that the finality test is satisfied where, although agency action is nonbinding, the agency's de facto position is "definitive" such that "the writing is on the wall" (quoting Nat'l Mining Ass'n v. McCarthy, 758 F.3d 243, 253 (D.C. Cir. 2014) (internal quotation marks omitted))). And indeed, a few years after writing for the Court in Bennett v. Spear, Justice Scalia himself wrote again for the Court and found reviewable a nonbinding interpretive rule, because the agency had treated it as "conclusive." See Whitman v. Am. Trucking Ass'ns, Inc., 531 U.S. 457, 477-79 (2001). 
cases, as in enforcement actions, are the paradigm of reviewable action for Justice Scalia. The hard case, then, involves the intermediate category (2): review of general binding rules, for example notice-and-comment rules, before they are applied in particular cases. In other words, the hard case involves the Abbott Laboratories v. Gardner ${ }^{10}$ question: When and to what extent are agency rules reviewable before they are enforced against particular parties?

On the Justice Stevens conception, of course, the answer is straightforward: pre-enforcement review is valid. Justice Scalia, by contrast, was reluctant to countenance pre-enforcement review, which threatens to undo his distinction between general programs or policies and specific applications. Justice Scalia, however, was constrained by the existence of adverse precedent, and generally acceded to pre-enforcement review, insofar as necessary. In that sense, consistent with his overall approach to adjudication and precedent, his treatment of reviewability was "faint-hearted." 11

\section{Two Conceptions of Reviewability-and of the Judicial Role}

\section{A. Review of Rules}

Agencies typically (although not necessarily) formulate policies and programs premised on some conception of their legal authority, the boundaries of their legal discretion; they enact general rules in pursuance of those programs; and they enforce the rules in particular cases. Given some commitment to preserving the rule of law, somehow defined, at which point or points in this sequence should judicial review occur? Here too, I will focus for the moment not on the threefold distinction among policies, rules, and applications, but rather on the distinction between general (policies and rules) and particular (applications). The differences among policies, rules, and applications will be explored later, when we discuss pre-enforcement review.

In the abstract, and stated at a very general level, two different approaches to reviewability are possible. On one view, the important thing is to ensure that the programs, policies, and rules of law under which the agency is proceeding are valid as formulated on their face. If agencies are formulating policies and rules that are generally invalid, there is a serious problem, one that it is imperative for courts to oversee and correct. If agencies are applying valid policies incorrectly in particular cases, that is unfortunate, but less grave.

On this approach, the application of policies and rules to particular cases is less important to review, for several reasons. First, the stakes are inherently cabined and confined. The application of policies and rules in particular cases can legally bind (if at all) only in the case at hand, whether or not it has defensible precedential effect in other cases. With respect to rules, the stakes are lower even if the rules are not formulated antecedently

10 Abbott Labs. v. Gardner, 387 U.S. 136, 139-40 (1966).

11 See, e.g., Antonin Scalia, Originalism: The Lesser Evil, 57 U. CIn. L. Rev. 849 (1989). 
in legislative style, through notice-and-comment proceedings, so that the agency qua adjudicator formulates rules as rationales in the process of application. In that situation, rules function as precedents, but are still not so binding as legislative rules; rules as precedents can be overturned in future cases (if reasons can be given for doing so), or can be distinguished away, whereas legislative rules are binding even upon the agency itself, unless and until changed through the same notice-and-comment process that created them.

Second, application of policies and rules to cases is mediated by agency determination of particular facts ("adjudicative facts"). Judicial review of adjudicative facts has always been deferential, especially in on-the-record proceedings where the "substantial evidence" test applies. ${ }^{12}$ The difference, then, between a finding of reviewability and a finding of unreviewability is less than it might otherwise be, if judicial review on the merits were plenary.

Third, policies and rules have effects that sweep well beyond the (small) subset of applications that end up being litigated in court. The anticipated effect of rules, even before they are enforced against anyone, is magnified tenfold by compliance bureaucracies in firms and nonprofit institutions; "the threat [of enforcement] is stronger than its execution." 13 In this practical sense, law consists in the compliance effect of rules, and judicial review of rules is necessary for there to be any judicially enforceable rule of law at allor so the argument would run. On this view, pre-enforcement review of rules-permitted under certain circumstances by Abbott Laboratories-is essential. ${ }^{14}$ This turns out to be an important difference between the two conceptions, a point to which I will return below.

In a number of opinions (both for the Court, and separately), Justice Stevens can be understood to have championed this conception. I will mention two of the most prominent. In McNary v. Haitian Refugee Center, Inc., the question was "whether $\S 210(\mathrm{e})$ of the Immigration and Nationality Act (INA) . . precludes a federal district court from exercising general federalquestion jurisdiction over an action alleging a pattern or practice of procedural due process violations by the Immigration and Naturalization Service (INS)." 15 The relevant statutory text said, in critical part, that "judicial review of a determination respecting an [immigration] application" was barred. ${ }^{16}$ The government argued that the plaintiffs' constitutional challenges to the INS's actions fell within the section; after all, the alleged violations did not

12 J. Skelly Wright, Courts and the Rulemaking Process: The Limits of Judicial Review, 59 Cornell L. Rev. 375, 391 (1974).

13 Edward Winter, A Nimzowitsch Story, Chess Notes (Jan. 31, 2017), http://www.chess history.com/winter/extra/nimzowitsch.html (quoting the Grandmaster as saying that "[t] he threat is stronger than its execution").

14 See Abbott Labs., 387 U.S. at 144-46.

15 McNary v. Haitian Refugee Ctr., Inc., 498 U.S. 479, 483 (1991).

16 Id. at 486 n.6 (quoting Immigration Reform and Control Act of 1986, Pub. L. No. 99-603, § 210 (e), 100 Stat. 3359, 3421). 
occur out of thin air, but with respect to action on applications. ${ }^{17}$ Justice Stevens, however, distinguished "judicial review of a determination respecting an application," 18 which he read to mean the application of general policies to particular cases, from what he called "general . . . challenges to unconstitutional practices and policies used by the agency in processing applications." 19 The latter were not covered by the statutory language. A crucial rationale for this reading was that, if read more expansively, the result would be "a total denial of judicial review of generic constitutional and statutory claims" 20 - which Justice Stevens treated as obviously unacceptable. The word "generic," as in "typical" and "general," does important work here; Justice Stevens was implicitly concerned to protect a judicial role in keeping government generally within the bounds of the law.

McNary cited and relied upon an earlier Justice Stevens opinion in a domestic-benefits context: Bowen v. Michigan Academy of Family Physicians. ${ }^{21}$ At issue were regulations under Part B of the Medicaid program, in particular the question whether a provision for judicial review of any "determination of the amount of benefits" under Part A precluded review under Part B by negative implication. ${ }^{22}$ The plaintiffs wanted to mount a general facial challenge to the validity of the Secretary's procedural method for calculating benefits. ${ }^{23}$ Justice Stevens, writing for the Court, sharply distinguished this sort of general challenge to the overall program from a challenge to the amount of individual determinations. ${ }^{24}$ The latter, he concluded, had been precluded, but not the former. ${ }^{25}$

$17 I d$. at 491 ("Petitioners' entire jurisdictional argument rests on their view that respondents' constitutional challenge is an action seeking 'judicial review of a determination respecting an application for adjustment of status' and that district court jurisdiction over the action is therefore barred by the plain language of $\S 210(\mathrm{e})(1)$ of the amended INA." (quoting 8 U.S.C. $\$ 1160$ (e) (1) (2012))).

$18 I d$. at 486 n.6 (quoting Immigration Reform and Control Act of $1986 \S 210(\mathrm{e})$ ).

$19 I d$. at 492.

20 Id. at 497.

21 Bowen v. Mich. Acad. of Family Physicians, 476 U.S. 667 (1986).

22 Id. at 674 n.5 (quoting 42 U.S.C. $§ 1395 f f(a)$ (1982)).

23 See id. at 668.

24 Id. at $674-78$.

25 See id. at 680-81. In a later case, Shalala v. Illinois Council on Long Term Care, Inc., 529 U.S. 1 (2000), the Court engaged in a confusing fight over the meaning of Bowen v. Michigan Academy of Family Physicians. Justice Breyer's opinion for the majority read Bowen somewhat differently than I have described it in text, see id. at 15-20; Justice Thomas argued in dissent that it undeniably did draw a distinction between programmatic challenges and challenges to individual determinations, see id. at 36-38 (Thomas, J., dissenting). Justice Stevens, the author of Bowen, joined his dissent. Id. at 32. It seems to me that Justice Thomas clearly had the better argument, and that the Court was reinterpreting Bowen for the occasion. But the merits of that question aren't essential for my enterprise here, which is merely to outline the Justice Stevens conception and to show its operation in a few real cases. 


\section{B. Review of Application}

Now let us turn to a different view altogether, championed by Justice Scalia, also in a series of opinions. On this conception, federal judges sit to decide particular "cases and controversies" litigated between parties, not to arbitrate the validity of rules per se. Questions of rules' validity may of course arise in the course of deciding cases, when necessary to a decision. But judicial authority to decide such questions is essentially a byproduct of the judges' narrower commission.

Justice Scalia consistently argued for this approach, most famously in cases of constitutional standing under the "case and controversy" requirement of Article III, ${ }^{26}$ but also in reviewability cases, properly so-called. Indeed, we may see Justice Scalia's reviewability jurisprudence as a sustained attempt to read the reviewability provisions of the APA in accordance with (his view of) background constitutional principles-a sustained application of the canon that statutes should be read, where it is fairly possible to do so, as constitutionally valid. Here too, I will confine myself to only two of the many possible examples.

In Lujan v. National Wildlife Federation ${ }^{27}$ —not to be confused with the more famous standing opinion by Justice Scalia in Lujan v. Defenders of Wildlife $e^{28}$ - the plaintiffs attempted to obtain review of a "land withdrawal review program" initiated by the Department of the Interior and the Bureau of Land Management (BLM). ${ }^{29}$ Justice Scalia laid out his approach to review of "policies" and "programs," and his approach to pre-enforcement review of binding agency rules as well. I will therefore quote his opinion at some length:

The term "land withdrawal review program" (which as far as we know is not derived from any authoritative text) does not refer to a single BLM order or regulation, or even to a completed universe of particular BLM orders and regulations. It is simply the name by which petitioners have occasionally referred to the continuing (and thus constantly changing) operations of the BLM in reviewing withdrawal revocation applications and the classifications of public lands and developing land use plans as required by the FLPMA. It is no more an identifiable "agency action"-much less a "final agency action"-than a "weapons procurement program" of the Department of Defense or a "drug interdiction program" of the Drug Enforcement Administration. As the District Court explained, the "land withdrawal review program" extends to, currently at least, "1250 or so individual classification terminations and withdrawal revocations."

Respondent alleges that violation of the law is rampant within this program-failure to revise land use plans in proper fashion, failure to submit certain recommendations to Congress, failure to consider multiple use, inordinate focus upon mineral exploitation, failure to provide required public

26 See, e.g., Lujan v. Defs. of Wildlife, 504 U.S. 555 (1992).

27 Lujan v. Nat'l Wildlife Fed'n, 497 U.S. 871, 875 (1990).

28 Lujan, 504 U.S. 555.

29 Nat'l Wildlife Fed'n, 497 U.S. at 875 (internal quotation marks omitted). 
notice, failure to provide adequate environmental impact statements. Perhaps so. But respondent cannot seek wholesale improvement of this program by court decree, rather than in the offices of the Department or the halls of Congress, where programmatic improvements are normally made. Under the terms of the APA, respondent must direct its attack against some particular "agency action" that causes it harm. Some statutes permit broad regulations to serve as the "agency action," and thus to be the object of judicial review directly, even before the concrete effects normally required for APA review are felt. Absent such a provision, however, a regulation is not ordinarily considered the type of agency action "ripe" for judicial review under the APA until the scope of the controversy has been reduced to more manageable proportions, and its factual components fleshed out, by some concrete action applying the regulation to the claimant's situation in a fashion that harms or threatens to harm him. (The major exception, of course, is a substantive rule which as a practical matter requires the plaintiff to adjust his conduct immediately. Such agency action is "ripe" for review at once, whether or not explicit statutory review apart from the APA is provided.)

....

. . Except where Congress explicitly provides for our correction of the administrative process at a higher level of generality, we intervene in the administration of the laws only when, and to the extent that, a specific "final agency action" has an actual or immediately threatened effect. Such an intervention may ultimately have the effect of requiring a regulation, a series of regulations, or even a whole "program" to be revised by the agency in order to avoid the unlawful result that the court discerns. But it is assuredly not as swift or as immediately far-reaching a corrective process as those interested in systemic improvement would desire. Until confided to us, however, more sweeping actions are for the other branches. ${ }^{30}$

In Norton v. Southern Utah Wilderness Alliance (SUWA), ${ }^{31}$ a rather similar challenge to a wilderness-management program of the Bureau of Land Management, Justice Scalia amplified upon the separation of powers rationale for his conception, noting that it serves a dual function: to protect agencies from judicial arrogation of executive functions, and to protect judges from entanglement with problems unsuitable for judicial resolution:

The principal purpose of the APA limitations we have discussed-and of the traditional limitations upon mandamus from which they were derived-is to protect agencies from undue judicial interference with their lawful discretion, and to avoid judicial entanglement in abstract policy disagreements which courts lack both expertise and information to resolve. If courts were empowered to enter general orders compelling compliance with broad statutory mandates, they would necessarily be empowered, as well, to determine whether compliance was achieved-which would mean that it would ultimately become the task of the supervising court, rather than the

30 Id. at 890-94 (footnote omitted) (citations omitted) (quoting Nat'l Wildlife Fed'n v. Burford, 699 F. Supp. 327, 332 (D.D.C. 1988)).

31 Norton v. S. Utah Wilderness All., 542 U.S. 55 (2004). 
agency, to work out compliance with the broad statutory mandate, injecting the judge into day-to-day agency management. ${ }^{32}$

Lujan v. National Wildlife Federation and Norton v. Southern Utah Wilderness Alliance together illustrate Justice Scalia's commitments. Put technically, agency programs and policies do not count as discrete "agency action" under the APA, and are therefore not reviewable (unless some other avenue of review happens to obtain). General rules may be reviewable under Abbott Laboratories, but only so long as the rule practically requires a regulated party to change his conduct immediately. Applications of rules in particular cases, by way of enforcement, are the only category in which reviewability uncontroversially obtains - the opposite of Justice Stevens's conception.

\section{The Two Conceptions, Compared}

What might be said on behalf of one conception or the other? I will try as far as possible to focus on the considerations that are more or less specific to the problem of reviewability in subconstitutional administrative law, as opposed to larger background debates about constitutional standing. As I have indicated, however, it is impossible fully to disentangle reviewability from larger conceptions of the constitutional roles and spheres of courts and agencies. ${ }^{33}$

On behalf of the Stevens view, it might be said that the basic task of the federal courts, at least in the modern era, is to keep the administrative state as a whole within the boundaries of law as a whole. On this view, the modern era is defined by an allocation of authority between agencies and courts laid out in Crowell v. Benson, ${ }^{34}$ Chief Justice Hughes's grand attempt to lay down a charter of demarcation for the boundaries of the administrative state. The Crowell demarcation had a number of features; one of them was an important distinction between de novo judicial authority to review (pure) questions of law, on the one hand, and deferential review of questions of fact, on the other. ${ }^{35}$ This distinction rests on an idea that questions of law are general, whereas questions of fact are particular to the parties and the case at hand.

But why draw such a distinction in the first place? What motivates it? In Crowell, Chief Justice Hughes's main idea was that de novo judicial review of legal rules was necessary to defend the rule of law from executive encroachment. Absent plenary judicial review of the legal validity of agency interpretation of statutes, the result would be "a government of a bureaucratic character alien to our system." 36 Now, technically speaking, Crowell is not a reviewability case (not least because, of course, it was decided fourteen years

$32 I d$. at $66-67$.

33 As Justice Scalia's concurrence in Webster v. Doe especially underscores. Webster v. Doe, 486 U.S. 592, 606-21 (1988) (Scalia, J., dissenting) (asserting that even APA reviewability turns on underlying constitutional principles of the allocation of roles between courts and the executive).

34 Crowell v. Benson, 285 U.S. 22 (1932).

$35 I d$. at 46.

$36 I d$. at 57. 
before the enactment of the APA, under a regime of reviewability that was both in flux and different than the APA regime). ${ }^{37}$ Its logic and rationale, however, are not so easily cabined. Although Chief Justice Hughes's reasoning was intended to justify de novo judicial review of legal questions on the merits, it might easily be extended to the logically antecedent question whether judges should have the authority to review agency legal interpretations in the first place.

On this approach, the crucial question would be whether reviewability is necessary (or at least appropriate) to ward off the creation of a "government of a bureaucratic character alien to our system." 38 To adapt an idea that Richard Fallon has suggested in various neighboring doctrinal settings, ${ }^{39}$ one might understand the master principle of reviewability doctrine to be that the role of courts is to keep government as a whole within the boundaries of law as a whole. This conception is deliberately framed in aggregate terms; it looks to the courts to police the overall legality of the administrative state, in a rough general way, even if particular agency actions stray near or even across the lines of legality.

As such, the conception fits quite naturally with the distinction between review of general agency rules that interpret statutes, on the one hand, and review of agency adjudications that apply interpretations to facts determined by the agency, on the other. The former sort of agency action governs a broad range of cases, binds both the agency itself and all the world subject to the rule, and induces compliance by a wide range of potentially regulated parties. Indeed, under some circumstances, agencies may use the fact of having made a rule to foreclose subsequent challenges to the rule's validity by regulated parties, who-at least so long as they had an opportunity to challenge the rule when promulgated-may be remitted to arguing solely over whether they have complied with the rule, not whether the rule itself is valid. ${ }^{40}$ In this sense, general rulemaking by agencies is intrinsically more consequential. The distinction is slightly complicated by the fact that agencies may of course issue legal interpretations in the course of adjudication. Yet those interpretations are always revisable in subsequent adjudications, so long as the agency gives a sufficient reason for doing so. The logical consequence of this picture is that judges should be more concerned to police general agency interpretations, especially but not only in rulemaking, than to police specific applications. And that is just what we see in Justice Stevens's jurisprudence.

So much for the animating motivations behind the Stevens view. What might be said on behalf of the Scalia view? A great deal. A standard claim in the literature-a claim whose truth is not my concern here, and that I will not spend any time evaluating-is that the text and history of Article III,

37 See Administrative Procedure Act, Pub. L. No. 79-404, 60 Stat. 237 (1946).

38 Crowell, 285 U.S. at 57.

39 See, e.g., Richard H. Fallon, Jr., "The Rule of Law" as a Concept in Constitutional Discourse, 97 Colum. L. Rev. 1, 53 (1997).

40 See Fed. Power Comm'n v. Texaco, Inc., 377 U.S. 33, 39-45 (1964). 
particularly its "case and controversy" language, bar any general judicial oversight of the legal validity of governmental action, including constitutional validity. Rather legal validity only ever becomes relevant in the course of deciding claims and defenses in particular cases. Such claims may also be tied to the larger structure of the Constitution, and to implicit constitutional principles of the separation of powers. ${ }^{41}$

Put differently, if the Stevens view rests on a master principle-that reviewability doctrine should allow judges to keep bureaucratic government as a whole within the boundaries of law as a whole, in some aggregate sense-then the Scalia view rests on a different, indeed competing, master principle: the law itself includes restraints on the authority of courts to keep other institutions within legal boundaries. As Justice Scalia's analysis for the Court in Norton $v$. SUWA indicates, those restraints are based in the separation of powers, and have a Janus-faced character, looking in two directions: they both protect the executive from interference by courts in the exercise of its discretionary judgments about programs, and also protect the courts themselves from the temptation to step beyond their area of constitutional and institutional competence, with risks of long-term harm.

If the consequence is that lawlessness at the level of program formulation goes unchecked by courts, that is doubtless a cost, but a cost that is mitigated by two considerations. First, unchecked by courts need not mean unchecked altogether, given the existence of congressional oversight and other checks. Second, whenever the executive wants to bring its program to the point of application, it will have to proceed in individual cases, at least with respect to programs that involve enforcement, licensing, and resource allocation as between competing claimants. In all these cases, the courts will stand open to review legality at the point of application.

On this alternative conception, the ability of courts to police the legal boundaries of the administrative state is not an end in itself, as in the Stevens conception. Whereas under that conception courts are limited to an aggregate form of review that checks the validity of general agency rules, but leaves agencies discretion to apply those rules to particular facts, the Scalia conception starts from the opposite end, implying that courts should be limited to reviewing the legal validity of agency rules as applied in particular cases. As we will see, however, Justice Scalia's self-described "faint-heartedness"-his willingness to abide by settled foundational precedents-caused him to compromise partially the strict logic of his view in an important class of cases involving pre-enforcement review of agency rulemaking. Let me now turn to that situation.

41 Bracketing the cogent view that there may not, in fact, be any such implicit general principles. See generally John F. Manning, Separation of Powers as Ordinary Interpretation, 124 Harv. L. REv. 1939 (2011). 


\section{Pre-Enforcement Review of Rules}

The operational difference between the two conceptions of reviewability I have sketched comes to the fore with respect to pre-enforcement review of agency rules under Abbott Laboratories-a theoretically crucial issue in administrative law, and one on which the Court is not as settled as the black-letter textbooks would have it. ${ }^{42}$ The issue is crucial because pre-enforcement review of rules has become one of the major constraints on the "rulemaking revolution" of the 1960s and 1970s. ${ }^{43}$ Absent such review, regulated parties would in many cases face a dilemma of compliance: obey now, or take action in possible violation of the rule and wait until enforcement to raise claims and defenses against the validity of agency action, at risk of suffering penalties for the violations if those claims and defenses fail. I do not say that it would be necessarily wrong or unjustified to inflict such a dilemma on regulated parties; I do not mean to address the merits of pre-enforcement review here. The only point is that such review is justified, if at all, as a means of allowing parties to obtain a judicial ruling on legality in advance of crossing the line between safe legality and possible violation. Of course, in order for the petition for pre-enforcement review to be ripe, there must be some plausible threat of enforcement or other injury; just not a consummated injury.

On the Justice Stevens conception, pre-enforcement review of general agency rules is straightforward; indeed the Justice Stevens conception, as in Washington $v$. Trump, would even allow review of policies, in which case review of notice-and-comment rules and other binding obligations follows $a$ fortiori. The more difficult question for the Justice Stevens conception is why, or whether, there should be any limitations on pre-enforcement review at all, at least so long as minimal Article III requirements (injury, causation, redressability, and adverseness) are satisfied. After all, whenever the agency promulgates a general rule that purports to bind all the world, the rationale behind the Justice Stevens conception-and behind Crowell v. Benson-is fully implicated. Absent pre-enforcement judicial review, the argument would run, regulated parties are in effect coerced de facto into compliance with administrative commands. In that sense, they will be subjected to "government of a bureaucratic character," which Crowell insisted is "alien to our system." 44

The Supreme Court, however, has never gone that far. It has insisted, ever since Abbott Laboratories, that pre-enforcement review is available when there is a concrete practical effect on regulated parties. ${ }^{45}$ The main doctrinal controversy in recent years has concerned the conditions under which

42 Compare McNary v. Haitian Refugee Ctr., Inc., 498 U.S. 479 (1991) (holding preenforcement review available), with Thunder Basin Coal Co. v. Reich, 510 U.S. 200 (1994), and Shalala v. Ill. Council on Long Term Care, Inc., 529 U.S. 1 (2000) (both holding preenforcement review unavailable).

43 See generally Richard J. Pierce, Jr., Rulemaking and the Administrative Procedure Act, 32 Tulsa L. Rev. 185 (1996).

44 Crowell v. Benson, 285 U.S. 22, 57 (1932).

45 See Abbott Labs. v. Gardner, 387 U.S. 136 (1966). 
pre-enforcement review will be unavailable-more specifically, whether the Court's "presumption of reviewability" creates a strong presumption that preenforcement review is available, or instead is fully satisfied so long as either pre-enforcement or post-enforcement review is available. In Shalala v. Illinois Council on Long Term Care, Inc., Justice Scalia even denied there is such a presumption in the Abbott Laboratories situation:

With regard to the timing of review, I would not even use the word "presumption" (a term which Abbott Laboratories v. Gardner applies only to the preference for judicial review at some point), since that suggests that some unusually clear statement is required by way of negation. In my view, preenforcement review is better described as the background rule, which can be displaced by any reasonable implication ("persuasive reason to believe," as Abbott Laboratories put it) from the statute. ${ }^{46}$

Overall, then, while Justice Scalia attempted to nudge doctrine away from a strong version of Abbott Laboratories, he never refused to follow the basic holding of that decision. ${ }^{47}$ That stance is very much in line with Justice Scalia's self-described "faint-hearted[ness]" about entrenched precedent. ${ }^{48}$ It should not, however, obscure the logic of his approach to reviewability, which looks askance at judicial review of general rules in advance of their application to particular parties. The crucial qualification that Justice Scalia underscored in Lujan v. National Wildlife Federation-that pre-enforcement review is available when regulated parties are compelled to change their behavior by the threat of enforcement—can be justified, on his approach, as an attempt to limit pre-enforcement review to situations where an "application" of the rule at least has occurred extrajudicially, in an extended metaphorical sense, if not in court. Not a perfect substitute, but apparently a tolerable one for Justice Scalia.

Confirmation of this picture is that when the question involved preenforcement review of targeted agency determinations rather than general policies or rules, the Justice had no qualms about expansive reviewability. Consider targeted agency determinations like the EPA "compliance orders"

46 Shalala, 529 U.S. at 32 (Scalia, J., dissenting) (citations omitted) (quoting Abbott Labs., 387 U.S. at 140).

47 See, e.g., Whitman v. Am. Trucking Ass'ns, Inc. 531 U.S. 457, 479 (2001) (applying Abbott Laboratories to allow pre-enforcement review of an interpretive rule). Even there, however, the Justice was clear to write as narrowly as possible, tying the outcome in part to special statutory features of the Clean Air Act:

Whether or not this would suffice in an ordinary case brought under the review provisions of the APA, we have characterized the special judicial-review provision of the CAA as one of those statutes that specifically provides for "preenforcement" review. Such statutes, we have said, permit "judicial review directly, even before the concrete effects normally required for APA review are felt." The effects at issue here surely meet that lower standard.

Id. at 479-80 (citations omitted) (quoting Lujan v. Nat'l Wildlife Fed'n, 497 U.S. 871, 891 (1990)).

48 Scalia, supra note 11 , at 862 . 
that the Court, with Justice Scalia writing, held reviewable in Sackett v. EPA ${ }^{49}$ in what was (technically at least) a pre-enforcement posture. The distinction between the Justice's approach in Sackett, on the one hand, and on the other his patent reluctance to license pre-enforcement review of general rules, in both Lujan and Illinois Council, is that the former involved something much closer to the adjudicative application of general policies to particular facts than did the latter. It thus fell on the reviewable side of Justice Scalia's basic conceptual distinction.

\section{IV. "The Rule of Law as a Law of Rules"}

Let me turn, finally, to a last point about Justice Scalia's theoretical contributions. Perhaps the most famous claim Justice Scalia ever advancedcertainly in extrajudicial writing - is that the "rule of law" can be understood as a "law of rules." 50 What connection does this have to the reviewability of rules in administrative law? Which of our two conceptions does this claim about the rule of law support?

One might argue, with some superficial plausibility, that if the rule of law is a law of rules, judges had better have the authority to review general and therefore rule-like agency action-certainly in advance of agency enforcement in particular cases, when agencies make binding general rules through rulemaking, but perhaps even earlier, when agencies formulate general policies. On this view, understanding the essence of the rule of law as rule-like generality implies that in order to keep government within the bounds of law, courts must be able to examine rules wherever they are to be found. (Ceteris paribus, of course; if there are special circumstances, such as the presence of sensitive national security or foreign policy concerns, then reviewability may be defeated on those grounds, but only on those grounds.)

I don't think this is the best conception, however, once we attempt to fit Scalia-qua-scholar together with Scalia-qua-judge, treating the two as presumptively consistent. Despite its framing as a claim about the rule of law in itself, as it were, apart from which judges or apart from which institutional forums apply law, Justice Scalia's claim is best understood as judge-referential-as primarily addressing the judicial role and judicial behavior. Indeed, Justice Scalia so announces right at the beginning of his famous article, saying that "[the] particular value of having a general rule of law is beside the point. For I want to explore the dichotomy between general rules and personal discretion within the narrow context of law that is made by the courts." 51 If others have misunderstood Justice Scalia, that is their fault, not his. He is not addressing the jurisprudence of rules qua rule, or the topic of rules versus standards ${ }^{52}$ in general-hanging in the air. Rather he is addressing a

49 Sackett v. EPA, 132 S. Ct. 1367, 1374 (2012).

50 Scalia, supra note 7.

$51 \quad I d$. at 1176.

52 See generally Louis Kaplow, Rules Versus Standards: An Economic Analysis, 42 Duke L.J. 557 (1992). 
much narrower (albeit still critical) topic: decision-procedures for adjudication in Article III courts. And this understanding fits seamlessly with his overall approach to reviewability, which attempts-insofar as is possible under extant doctrine-to confine courts to review of the application of general rules to particular cases.

On this understanding, what work does the commitment to seeing the rule of law as a "law of rules" actually do? It works, not as a statement of what counts as a legal rule the judges may assess for validity, but rather as a constraint on the types of rationales the judges may offer when a case or controversy is properly before them. The "law of rules" vision is that, when deciding upon a case that reviews the application of a general rule to particular facts, the judges are constrained to offer rationales that operate at a sufficiently high level of generality above, as it were, the facts of the particular case. The judge must offer a rationale that derives from and embodies a "clear rule of decision' based on "general principles." 53 The advantages of this approach, for Justice Scalia, were that general rules provide clarity and predictability; embolden judges in future cases by giving them a clear rule to point to; and-most interesting of all—tie the judges' own hands against unprincipled political opportunism in future cases.

When combined with Justice Scalia's approach to reviewability, discussed earlier, the result is faintly paradoxical, although there is no flaw in the logic (whether or not Justice Scalia's conception is ultimately correct as well as coherent-an issue I am bracketing). The combination is seemingly paradoxical because it looks in two directions simultaneously. At the stage of reviewability, it attempts to filter out judicial scrutiny of general policies and even (to the extent consistent with Abbott Laboratories) judicial scrutiny of general binding rules, until they are applied in particular cases. The approach at this stage is to cabin judges to particular applications in particular cases. Once the hurdle of reviewability is leapt over and the merits are reached, however, the combined conception turns right around and attempts to raise rather than lower the level of generality of judicial action-requiring judges to offer rules of decision that are general and binding, including binding on the judges themselves.

When we bring Justice Scalia's jurisprudence of reviewability together with his jurisprudence of rules, then, a coherent vision emerges. Insofar as prevailing doctrine allows (in other words, subject to the constraint of Abbott Laboratories), federal judges must decide only specific applications to specific cases, but must decide those specific cases only on the basis of general rules. The opposite of this conception is a judge who wants broad scope for judicial review of general rules, pre-enforcement, or even broad agency policies, and yet who also thinks that judicial restraint often counsels relatively case-specific or narrow rationales for decision. (Justices Stevens, O'Connor, and Ginsburg are all plausible candidates for this combination of views.) I believe that both positions hang together coherently, and that the choice between

53 Scalia, supra note 7 , at 1185 . 
them must be made on extrinsic grounds. This is not the place to arbitrate that dispute; my aim has been merely to elicit the logic of Justice Scalia's view, which I believe to be distinctive, coherent, and undeniably plausible. 